\title{
The Nonerythropoietic Component of Early Bilirubin
}

\author{
M. Levitt, B. A. Schacter, A. Zipursky, and L. G. Israels \\ From the Departments of Medicine and Pediatrics, University of Manitoba and the \\ Manitoba Cancer Treatment and Research Foundation, Winnipeg 3, Canada
}

A в S T R A C T The early labeled bilirubin consists of two primary components. The more rapidly synthesized of the two is independent of erythropoiesis (nonerythropoietic), whereas the second fraction is related to red cell production (erthyropoietic). The present studies concern the origin of the nonerythropoietic component.

The nonerythropoietic, early labeled bilirubin was studied in bile fistula rats with (delta ALA)$4-{ }^{14} \mathrm{C}$ delta aminolevulinic acid and glycine- $2-{ }^{14} \mathrm{C}$ as precursors. That nephrectomy did not reduce the size of this component despite the large and rapidly turning over pool of renal heme suggests that this pool may be of minor importance in its production. Intoxication with lead to a level that reduced hepatic heme synthesis was associated with a decrease in early bilirubin formation. The synthesis of this bilirubin was assessed in animals with phenobarbital-induced heme protein and cycloheximide-suppressed protein synthesis. Rats pretreated with phenobarbital at a dose level of 60 $\mathrm{mg} / \mathrm{kg}$ with induction of cytochrome P-450 synthesis showed a minor increase in early labeling when glycine- $2-{ }^{14} \mathrm{C}$ but not when delta ALA$4-{ }^{14} \mathrm{C}$ was used as precursor. Rats given cycloheximide at a dose level that markedly reduced hepatic protein and cytochrome P-450 synthesis but allowed heme synthesis to continue at $60 \%$ of its pretreatment level synthesized normal or increased amounts of early bilirubin from delta ALA-4- ${ }^{14} \mathrm{C}$. Allylisopropylacetamide intoxication caused little change in early bilirubin formation, whereas aminotriazole given at a time after maxi-

Dr. Levitt is a fellow, Medical Research Council of Canada. Dr. Schacter is a fellow, National Cancer Institute of Canada.

Received for publication 7 September 1967 and in revised form 19 December 1967. mal hepatic heme labeling produced a small but significant increase in the appearance of labeled bilirubin.

These findings indicate that early bilirubin production is little influenced by increased hepatic porphyrin synthesis or by changes in the rapidly turning over heme protein $\mathrm{P}-450$. A minimal increase attends catalase inactivation by aminotriazole. Normal or increased synthesis takes place in the presence of suppression of protein synthesis. This finding suggests that the nonerythropoietic early bilirubin may itself consist of two subcomponents. The first of these may arise from free tissue heme or its precursors, and the second may derive from the turnover of the heme proteins. The first subcomponent may serve as a regulatory mechanism for the removal of heme synthesized in excess of its protein acceptor. A composite scheme is proposed for the origin of the total early bilirubin from heme compartments in tissue and marrow.

\section{INTRODUCTION}

That $10-20 \%$ of the bile pigments excreted in normal man originate from sources other than the catabolism of the heme of senescent circulating red cells was first documented by London, West, Shemin, and Rittenberg (1) and by Gray, Neuberger, and Sneath (2). This fraction was identified by the appearance of ${ }^{15} \mathrm{~N}$-labeled stercobilin within 10 days of feeding glycine- ${ }^{15} \mathrm{~N}$. Subsequent studies utilizing intravenous glycine- $2-{ }^{14} \mathrm{C}$ and delta aminolevulinic acid (delta ALA) $-4-{ }^{14} \mathrm{C}$ in man, dogs, and rats have shown that bilirubin- ${ }^{14} \mathrm{C}$ is produced within minutes of the injection of the precursor $(3,4)$. This early labeled bilirubin consists of two major components $(5,6)$. The second component reaches peak activity in man $2-5$ 
days after administration of tracer glycine, can be altered by stimulating or suppressing erythropoiesis, and is thought to be primarily of erythropoietic origin. The first component appears within minutes of the administration of tracer glycine or delta ALA, quickly reaches maximum activity, and is largely excreted within $24 \mathrm{hr}$. This component is not affected by factors which alter erythropoiesis and, as tissue heme turnover has been considered its major source, it has been designated the nonerythropoietic component. The relative sizes of these two components may show species differences, the nonerythropoietic component being the major source of early labeled bilirubin in the rat (7).

After the administration of deltaALA $-{ }^{14} \mathrm{C}$ there is sufficient incorporation and turnover in hepatic and renal heme to account for all the early bilirubin- ${ }^{14} \mathrm{C}$ produced in bile fistula dogs $(8)$. Direct evidence of hepatic participation comes from the isolated perfused rat liver system which is able to synthesize labeled bilirubin from glycine- $2-{ }^{14} \mathrm{C}$ and delta ALA-4- ${ }^{14} \mathrm{C}$ at a rate and magnitude comparable to the rate of synthesis of early labeled pigment in the intact rat (9).

The direct precursors of the nonerythropoietic early bilirubin have not been established. We had suggested that it arises from at least two sources and can be resolved into two subcomponents (10). The first subcomponent may originate from one or more rapidly synthesized and degraded tissue heme proteins or from the direct conversion of free heme or heme precursors. The second subcomponent was thought to be derived from the turnover of the longer-lived tissue heme proteins.

If the hepatic heme proteins are a major source of these subcomponents, then an increase in their turnover should be reflected in an increase in early bilirubin. Schmid, Marver, and Hammaker (11) recently demonstrated in rats treated with phenobarbital a fourfold increase in glycine- $2-{ }^{14} \mathrm{C}$ incorporation into bile bilirubin, along with an eightfold increase in levels of liver microsomal cytochrome P-450, and a smaller increase in cytochrome $b_{5}$. They concluded that the parallel increase in labeled bilirubin excretion and microsomal cytochrome levels suggested that the microsomal cytochromes are a major source of early labeled bilirubin.

In the present study we have examined the role of renal heme and the effects of allylisopropylacetamide (AIA), aminotriazole (AT), and lead on the nonerythropoietic component of the early labeled bilirubin. AIA was selected as experimental porphyria in rats, is associated with a sharp increase in heme precursors, a drop in liver catalase, and normal or increased heme synthesis (12). Aminotriazole reduces hepatic catalase activity by forming an inactive irreversible complex with the enzyme (13). The kinetics of disposal of this complex are unknown, but it might be expected that this complexing is followed by rapid catalase destruction. Lead was used as an inhibitor of heme synthesis (14). To more directly examine the relationship of early bilirubin to hepatic heme and protein synthesis, we have studied the production of this bilirubin in rats in which heme protein synthesis is induced with phenobarbital, rats in which hepatic protein synthesis is inhibited by cycloheximide, and rats in which hepatic protein and total heme synthesis are depressed by bile duct ligation.

\section{METHODS}

\section{General procedures}

Male Sprague-Dawley rats weighing between 250 and $400 \mathrm{~g}$ were used throughout the experiments. They received a standard laboratory diet consisting of Purina Fox Chow and had free access to water. The tracer material used in all cases was $1 \mu \mathrm{c}$ of delta ALA-4- $-{ }^{14} \mathrm{C}^{1}$ with specific activity of $25-30 \mathrm{mc} / \mathrm{mmole}$ and either 20 or $100 \mu \mathrm{c}$ of glycine- $2-{ }^{14} \mathrm{C}$ with specific activity of $17-27 \mathrm{mc} /$ mmole. The route of tracer administration was by tail vein injection.

Bile fistulae were established under light ether anesthesia. The animals were then placed in Bollman cages (15), and the tracer was given either within $3 \mathrm{hr}$ of surgery or after an 18-24 hr recovery period. The first three bile collections were for 1-hr intervals, followed by collection for the period from 3-6 hr, 6-12 hr, and 12-24 hr after administration of the tracer. Bile was collected in a darkened room, and a trace of ascorbic acid was placed in the collection tubes.

\section{Isolation of bilirubin}

To facilitate extraction, carrier bilirubin was added to small bile samples. Bilirubin was then extracted fiom the bile and crystallized by the method of Ostrow, Hammaker, and Schmid (3). It was then redissolved in chloroform and further purified by alumina-column chromatography $(5,16)$. The crystallized bilirubin was dissolved in chloroform and plated in duplicate in aliquots of 0.05 $0.1 \mathrm{mg}$ at infinite thinness. Radioactivity was counted in

1 New England Nuclear Corp., Boston, Mass. 
a Nuclear-Chicago low background gas flow counter. The initial bile bilirubin concentration and the amount of bilirubin plated was determined by a modification of the diazo method of Malloy and Evelyn (17). The specific activity and total radioactivity of bilirubin in each bile sample were determined.

\section{Isolation of heme}

To study tracer incorporation into heme, animals were killed at intervals up to $24 \mathrm{hr}$ after injection, livers and kidneys were rapidly excised, perfused with cold saline, and frozen within $5 \mathrm{~min}$ pending heme extraction. Immediately after thawing, the liver and kidneys were homogenized in 4-5 volumes of water, first in a Waring blendor, and finally in a Potter-Elvehjem homogenizer with a teflon pestle. $100 \mathrm{mg}$ of carrier heme in the form of human hemoglobin was added to each homogenate, and heme was extracted by the method of Labbe and Nishida (18). Each heme sample was dissolved in $0.1 \mathrm{~N}$ $\mathrm{NaOH}$ and plated in 1-mg quantities. The planchets were counted in a Nuclear-Chicago gas flow counter and the total radioactivity determined as a percentage of the total injected counts.

\section{Isolation of protein}

Protein was isolated from rat liver homogenate by a modification of the method of Kassenaar, Morell, and London (19) for globin isolation and purification. After isolation, the protein was plated in $100-\mathrm{mg}$ quantities for counting. Results were expressed as $\mathrm{cpm} / \mathrm{mg}$ of hepatic protein, after correction for self-absorption.

\section{Cytochrome P-450}

The liver was excised and immediately perfused with $0.85 \% \mathrm{NaCl}$, weighed, and then homogenized with 4 volumes of $1.15 \% \mathrm{KCl}$ in a Potter-Elvehjem homogenizer. After centrifugation at $12,000 \mathrm{~g}$ for $25 \mathrm{~min}$, the microsomes were sedimented from the supernatant by centrifugation at $100,000 \mathrm{~g}$ for $30 \mathrm{~min}$. The microsomal pellet was washed once with $1.15 \% \mathrm{KCl}$, and the microsomes were again sedimented. Cytochrome $\mathrm{P}-450$ was assayed by measuring the CO-difference spectrum of a dithionite reduced microsome suspension according to the method of Omura and Sato (20). Cytochrome P-450 was quantitated on the basis of a molar extinction coefficient between 450 and $490 \mathrm{~m} \mu$ of $91 \mathrm{~cm} / \mathrm{mmole}$ per liter (21). The mean hepatic cytochrome $\mathrm{P}-450$ concentration in six control rats was $1.05 \mu \mathrm{mmoles} / \mathrm{mg}$ of microsomal protein. This value compares with an average of $1.55 \mu$ mmoles of cytochrome P-450 per $\mathrm{mg}$ of microsomal protein in 40 rabbits studied by Omura and Sato (20).

\section{Nephrectomy}

Both kidneys were removed, bile duct cannulation was carried out at a single operation in four animals, and the delta $\mathrm{ALA}-4-{ }^{14} \mathrm{C}$ was injected $3 \mathrm{hr}$ thereafter. In three other rats the ureters were ligated, the bile duct cannu- lated, and delta ALA-4- ${ }^{14} \mathrm{C}$ given $3 \mathrm{hr}$ later. These animals survived and excreted bile for another 30-50 hr. That delta ALA $-4-{ }^{14} \mathrm{C}$ was incorporated into renal heme in rats with ureteral ligation was confirmed in three rats in which the renal heme was isolated from the kidneys which were removed 60 min after $1 \mu \approx$ of delta ALA $-4-{ }^{14} \mathrm{C}$ was injected.

\section{Allylisopropylacetamide (AIA)}

AIA was administered subcutaneously suspended in propylene glycol at 12 -hr intervals over a period of 5 days to a total dose of $2 \mathrm{~g} / \mathrm{kg}$. These rats became lethargic, anorexic, and sustained a $10-25 \%$ weight loss. Bile fistulae were established, and only those rats with strongly fluorescent bile were considered porphyric. These animals received $1 \mu \mathrm{c}$ of delta ALA-4- ${ }^{14} \mathrm{C}$ intravenously, and bile collections were carried out as described.

\section{Aminotriazole}

Bile fistulae were established in six rats. After an 18$24 \mathrm{hr}$ recovery period delta ALA $-4-{ }^{14} \mathrm{C}$ was injected intravenously, and bile collections were begun. 3-amino-1,2,4triazole $(50 \mathrm{mg} / \mathrm{ml}$ in $0.9 \%$ saline $)$ in a dose of $1 \mathrm{~g} / \mathrm{kg}$ was injected subcutaneously $12 \mathrm{hr}$ after the injection of delta ALA $-4-{ }^{14} \mathrm{C}$. Bile was collected for $12 \mathrm{hr}$ after aminotriazole injection.

\section{Lead}

Six Sprague-Dawley rats were given $150 \mathrm{mg} / \mathrm{kg}$ of lead acetate subcutaneously as a $2 \%$ solution in distilled water. Two rats were given $1 \mu \mathrm{c}$ of delta ALA $-4-{ }^{14} \mathrm{C} 6$ days after injection, and $1 \mathrm{hr}$ later the rats were killed, and the incorporation of ${ }^{14} \mathrm{C}$ into hepatic heme was determined. Bile fistulae were established in four rats 5 days after lead acetate injection, and on the 6th day $1 \mu \mathrm{c}$ of delta ALA- $-4{ }^{14} \mathrm{C}$ was given intravenously, bile was collected for $24 \mathrm{hr}$, and the incorporation of ${ }^{14} \mathrm{C}$ into bilirubin measured.

\section{Phenobarbital-treated rats}

Incorporation of ${ }^{14} \mathrm{C}$ into bile bilirubin. Male SpragueDawley rats weighing between 250 and $400 \mathrm{~g}$ received daily subcutaneous injections of phenobarbital at dose levels of either 40,60 , or $80 \mathrm{mg} / \mathrm{kg}$ for 5 consecutive days. Control rats were given injections of an equivalent volume of $0.85 \%$ saline. The rats received a normal diet throughout the experiment, except for those starved for the final $48 \mathrm{hr}$ preceding the establishment of a bile fistula under ether anesthesia. The starved rats were not fed during the period of bile collection, but all rats were allowed water ad lib. A sixth dose of phenobarbital was given after surgery. 18-24 hr after surgery, the rats were given $1 \mu \mathrm{c}$ of delta ALA-4- ${ }^{14} \mathrm{C}, 20 \mu \mathrm{c}$ of glycine-2${ }^{14} \mathrm{C}$, or $100 \mu \mathrm{c}$ of glycine-2- ${ }^{14} \mathrm{C}$ by tail vein injection.

Cytochrome $P-450$. The rats were given injections of phenobarbital at a dose level of $20,40,60$, or $80 \mathrm{mg} / \mathrm{kg}$ for 5 consecutive days. Control rats were given an equiva- 
lent volume of saline. Some of the rats were starved for the final 2 days of the course of phenobarbital injections. On the 6th day, the rats were killed, and the livers were removed and assayed for cytochrome P-450.

\section{Cycloheximide-treated rats}

Cycloheximide is known to be a potent inhibitor of protein synthesis, both in vivo $(22,23)$ and in vitro (24). It was used in vivo in these studies as an inhibitor of hepatic protein synthesis. The experimental conditions and assays were as follows:

Incorporation of delta $A L A-4-{ }^{14} C$ into bile bilirubin. 18-24 hr after the establishment of a bile fistula under ether anesthesia, cycloheximide, $1 \mathrm{mg} / \mathrm{kg}$, was given subcutaneously. At 1 or $2 \frac{1}{2} \mathrm{hr}$ after cycloheximide administration, $1 \mu \mathrm{c}$ of delta ALA $-4-{ }^{14} \mathrm{C}$ was given by tail vein injection and bile collection carried out over a period of 12-24 hr.

Hemin ${ }^{14} \mathrm{C}$ conversion to bile bilirubin. $1 \mathrm{mg}$ of crystalline hemin $-{ }^{14} \mathrm{C}$ containing $32,000 \mathrm{cpm} / \mathrm{mg}$ was dissolved in $1 \mathrm{~N}$ sodium hydroxide, buffered to $\mathrm{pH} 7.5$ with $1.0 \mathrm{M}$ Tris buffer, and added to an equal volume of rat serum. The dissolved hemin was injected through a tail vein catheter into four bile fistula rats. Two of the rats were given $1 \mathrm{mg} / \mathrm{kg}$ of cycloheximide $1 \mathrm{hr}$ before infusion of radioactive hemin and compared with the two rats not given cycloheximide.

Glycine-2-24 $\mathrm{C}$ incorporation into hepatic protein. $18-24$ $\mathrm{hr}$ after establishment of a bile fistula, rats were given 1 $\mathrm{mg} / \mathrm{kg}$ of cycloheximide subcutaneously. Control rats were given an equivalent volume of saline. At zero time, $1,2.5,4.5$, or $8.5 \mathrm{hr}$ after cycloheximide administration, the rats were given $20 \mu \mathrm{c}$ of glycine-2- ${ }^{14} \mathrm{C}$ by tail vein injection. $90 \mathrm{~min}$ after tracer glycine administration (i.e. at $1.5,2.5,4,6$, and $10 \mathrm{hr}$ after cycloheximide administration) the rats were killed, their livers removed, and the protein isolated.

Delta $A L A-4-{ }^{14} C$ incorporation into hepatic heme. Bile fistula rats were treated with cycloheximide as described in the preceding section. At the same time intervals, the rats were given $1 \mu \mathrm{c}$ of delta $\mathrm{ALA}-4-{ }^{14} \mathrm{C}$ by tail vein injection. $90 \mathrm{~min}$ later, the rats were killed, their livers removed, and the heme isolated.

Cytochrome P-450. 24 male Sprague-Dawley rats were given $60 \mathrm{mg} / \mathrm{kg}$ of phenobarbital for 5 consecutive days to induce high initial levels of cytochrome P-450 $(25,26)$. Eight control rats received no phenobarbital pretreatment. On the day of the experiment, each animal was given 1 $\mathrm{mg} / \mathrm{kg}$ of cycloheximide subcutaneously. At hourly intervals for $6 \mathrm{hr}$ and again at $10 \mathrm{hr}$ after cycloheximide administration, one control and three phenobarbital-treated rats were killed and their livers removed and assayed for cytochrome P-450.

\section{Bile duct ligation}

Complete extrahepatic biliary tract obstruction was accomplished by ligation of the common bile duct. $40-48 \mathrm{hr}$ after ligation, bile fistulae were established, and 2-3 $\mathrm{hr}$ later the rats were given $20 \mu \mathrm{c}$ of glycine-2- ${ }^{14} \mathrm{C}$, killed 90 min thereafter, and the livers removed for isolation of protein. Similarly, $24 \mathrm{hr}$ after establishment of a bile fistula, three control rats were given glycine-2- ${ }^{14} \mathrm{C}$, and hepatic protein was isolated after $90 \mathrm{~min}$. Hepatic cytochrome P-450 was assayed in four rats $48 \mathrm{hr}$ after ligation of the common bile duct.

\section{RESULTS}

Control values for incorporation of delta ALA$4-{ }^{14} \mathrm{C}$ into bilirubin in bile over a $24 \mathrm{hr}$ period in eight bile fistula rats are presented in Fig. 1. The mean $24 \mathrm{hr}$ bilirubin- ${ }^{14} \mathrm{C}$ excretion in these animals was $24.0 \% \pm 2.4 \mathrm{SD}$ of the injected counts.

\section{Nephrectomy}

In the four nephrectomized rats the total $24 \mathrm{hr}$ incorporation of delta ALA-4- ${ }^{14} \mathrm{C}$ into bilirubin was $32.4,34.6,37.5$, and $60.4 \%$. No consistent alteration in the pattern of bilirubin labeling was observed. In those rats with bilateral ureteral ligation the incorporation was $21.9,24$, and $26.5 \%$. In three similar rats whose ureters were ligated 3 hr before $1 \mu \mathrm{c}$ of delta ALA-4- ${ }^{14} \mathrm{C}$ was given, the incorporation into renal heme at $1 \mathrm{hr}$ was 10.4 , 10.5 and $13 \%$ of the injected counts. The $1 \mathrm{hr}$ incorporation in four control rats was $8.1 \% \pm 4.1$, SD (10). Thus in rats with ureteral ligation heme synthesis from delta ALA was maintained for at least $3 \mathrm{hr}$, and in these animals early labeled bilirubin was produced at the same rate as in the control group. In rats with bilateral nephrectomy early labeling of bilirubin persisted at a level above that of the normal control group $(P<0.01)$.

\section{Allylisopropylacetamide (AIA)}

The mean $24 \mathrm{hr}$ incorporation of delta ALA${ }^{14} \mathrm{C}$ into bilirubin in three rats was $24.4 \% \pm 6.3$, SD which is of the same order as the controls. The distribution of this labeling over the $24 \mathrm{hr}$ period is shown in Table I and differs little from the controls but for a moderate but significant increase $(P<0.05)$ in the $0-3 \mathrm{hr}$ period. Robinson, Tsong, Brown, and Schmid found no increase in the incorporation of glycine-2- ${ }^{14} \mathrm{C}$ into the early bilirubin in an AIA-treated rat (7).

\section{Aminotriazole (AT)}

No abrupt increase in labeled bilirubin was observed after aminotriazole administration. However the bilirubin $-{ }^{14} \mathrm{C}$ excretion was significantly 


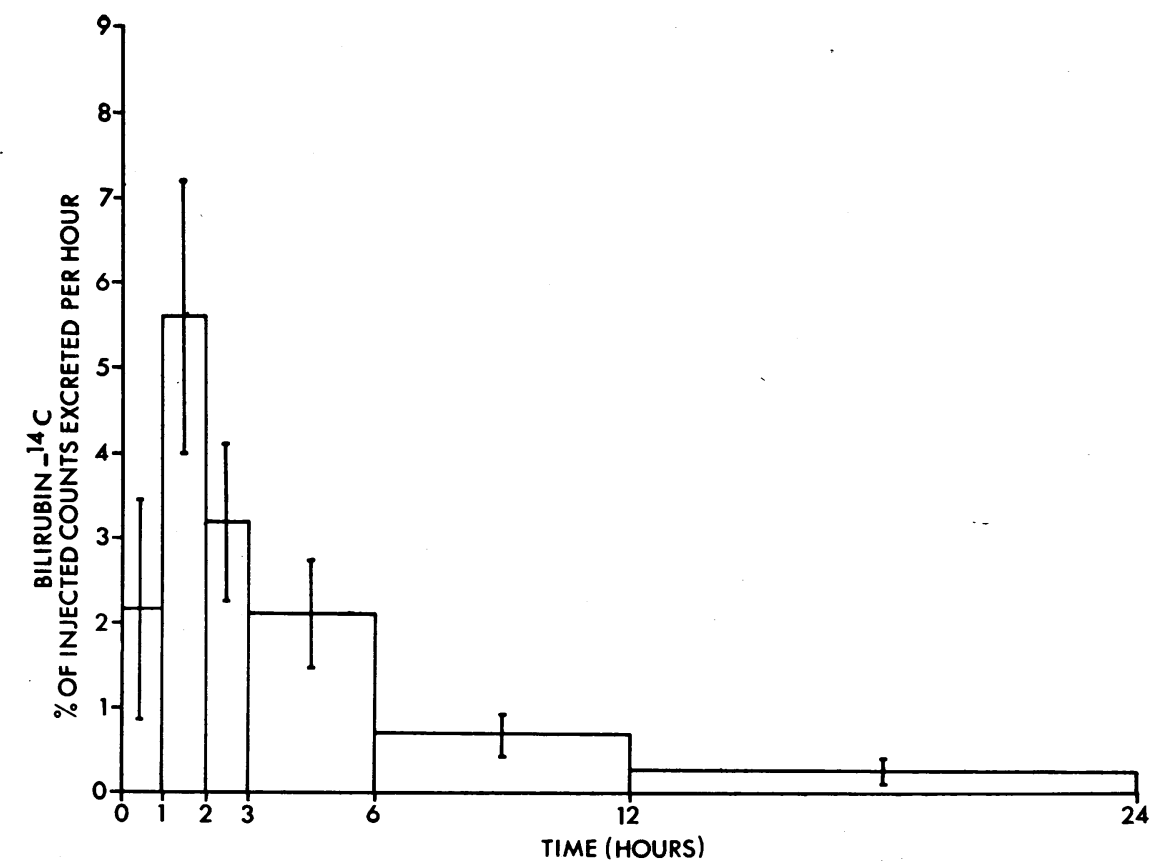

FiguRE 1 The excretion of bilirubin ${ }^{14} \mathrm{C}$ in eight bile fistula rats injected with $1 \mu \mathrm{c}$ of delta aminolevulinic acid (delta ALA) $-4-{ }^{14} \mathrm{C}$ at zero time. The results are expressed as the percentage (mean and standard deviation) of injected counts excreted per hour during each collection period.

increased in the total $12 \mathrm{hr}$ period $(P<0.01)$. The bilirubin- ${ }^{14} \mathrm{C}$ excretion during this interval (12th-24th hr after delta ALA-4- ${ }^{14} \mathrm{C}$ was $5.48 \%$ $\pm 1.25, \mathrm{sD}$ in six AT rats and $3.69 \% \pm 1.61, \mathrm{sD}$ in 16 control animals.

Lead

The mean incorporation of ${ }^{14} \mathrm{C}$ into hepatic heme 60 min after delta ALA-4- ${ }^{14} \mathrm{C}$ was $3.98 \%$ as compared with $11.8 \% \pm 1.3$, sD in six control rats (10). The incorporation into bilirubin was reduced within the first $3 \mathrm{hr}$ to $6.49 \% \pm 3.82$, sD as compared with $10.93 \% \pm 2.04$, SD in the control animals $(P<0.02[$ Table I] $)$.

\section{Phenobarbital-treated rats}

Cytochrome P-450. Administration of phenobarbital for 5 days in doses ranging up to $80 \mathrm{mg} /$ $\mathrm{kg}$ each day resulted in induction of cytochrome P-450 to levels approximately four times those of the control animals. These results are shown in Fig. 2. Although there is a high degree of variability, the level of induction does rise with increasing dosage of phenobarbital (26).
Incorporation of glycine-2- ${ }^{14} \mathrm{C}$ and delta $A L A$ $4-{ }^{14} \mathrm{C}$ into bile bilirubin. The $24 \mathrm{hr}$ incorporation of glycine-2- ${ }^{14} \mathrm{C}$ and delta ALA-4- ${ }^{14} \mathrm{C}$ into bilirubin in bile fistula rats pretreated with varying doses of phenobarbital is given in Table II. Phenobarbital produced a statistically significant increase in the incorporation of glycine-2- ${ }^{14} \mathrm{C}$ into bilirubin excreted in bile at dose levels of $60 \mathrm{mg} / \mathrm{kg}(P<$ $0.2)$ and $80 \mathrm{mg} / \mathrm{kg}(P<0.05)$. Starvation did not have any consistent effect on ${ }^{14} \mathrm{C}$ incorporation, and these animals are included in the mean values for each group. No significant increase in delta ALA-4-14C incorporation into bilirubin was demonstrated at a dose level of $60 \mathrm{mg} / \mathrm{kg}$ of phenobarbital. However at $80 \mathrm{mg} / \mathrm{kg}$ there was a significant increase in incorporation $(P<0.02)$.

There was no statistically significant difference between the $24 \mathrm{hr}$ bilirubin excretions for 14 rats treated with either 60 or $80 \mathrm{mg} / \mathrm{kg}$ of phenobarbital as compared with 14 control rats. The mean $24 \mathrm{hr}$ excretion in the controls was $1.31 \pm$ $0.31, \mathrm{SD}$, whereas in the 14 phenobarbital-treated animals the mean $24 \mathrm{hr}$ excretion was $1.55 \mathrm{mg} \pm$ 0.30 , sD. 
TABLE I

Per cent Incorporation of Delta $A L A-4-{ }^{14} C$ into Bile Bilirubin

\begin{tabular}{|c|c|c|c|c|c|c|}
\hline & \multirow[b]{2}{*}{$\mathrm{Hr} \ldots \ldots \ldots \ldots \ldots \ldots$} & \multicolumn{4}{|c|}{ Intervals of bile collection after injection of delta ALA-4-14C } & \multirow[b]{2}{*}{ Total } \\
\hline & & $0-3$ & $3-6$ & $6-12$ & $12-24$ & \\
\hline & $\begin{array}{c}\text { Controls, } \\
n=8\end{array}$ & $10.9 \pm 2.04$ & $6.29 \pm 1.90$ & $4.03 \pm 1.51$ & $2.75 \pm 1.74$ & $24.0 \pm 2.37$ \\
\hline & $\begin{array}{c}\mathrm{AIA}, 2 \mathrm{~g} / \mathrm{kg} \\
\mathrm{n}=3\end{array}$ & $15.4 \pm 4.87$ & $5.25 \pm 2.53$ & $2.41 \pm 0.87$ & $1.28 \pm 0.37$ & $24.3 \pm 6.3$ \\
\hline - & $\begin{array}{l}\text { Lead acetate, } \\
\qquad \begin{array}{l}150 \mathrm{mg} / \mathrm{kg} \\
\mathrm{n}=4\end{array}\end{array}$ & $6.49 \pm 3.82$ & $6.18 \pm 1.49$ & $3.80 \pm 1.69$ & $\begin{array}{c}3.08 \pm 0.51 \\
(\mathrm{n}=2)\end{array}$ & $\begin{array}{c}21.3 \pm 0.15 \\
(\mathrm{n}=2)\end{array}$ \\
\hline & $\begin{array}{l}\text { Phenobarbital, } \\
60 \mathrm{mg} / \mathrm{kg} \text { or } \\
80 \mathrm{mg} / \mathrm{kg} \\
\times 5 \text { days, } \\
\mathrm{n}=5\end{array}$ & $13.2 \pm 2.41$ & $5.68 \pm 1.02$ & $4.70 \pm 1.63$ & $3.91 \pm 1.72$ & $27.5 \pm 2.68$ \\
\hline & $\begin{array}{l}\text { Cycloheximide, } \\
1 \mathrm{mg} / \mathrm{kg} ; \\
\text { tracer given } \\
1 \mathrm{hr} \text { after, } \\
\mathrm{n}=4\end{array}$ & $13.9 \pm 6.07$ & $8.79 \pm 1.47$ & $6.96 \pm 0.92$ & $2.76 \pm 1.00$ & $32.4 \pm 4.82$ \\
\hline & $\begin{array}{l}\text { Tracer given } \\
\begin{array}{l}2.5 \mathrm{hr} \text { after, } \\
\mathrm{n}=5\end{array}\end{array}$ & $11.4 \pm 1.75$ & $9.72 \pm 1.82$ & $6.24 \pm 1.44$ & $2.76 \pm 1.76$ & $30.1 \pm 3.1$ \\
\hline
\end{tabular}

Delta ALA, delta aminolevulinic acid; AIA, allylisopropylacetamide.

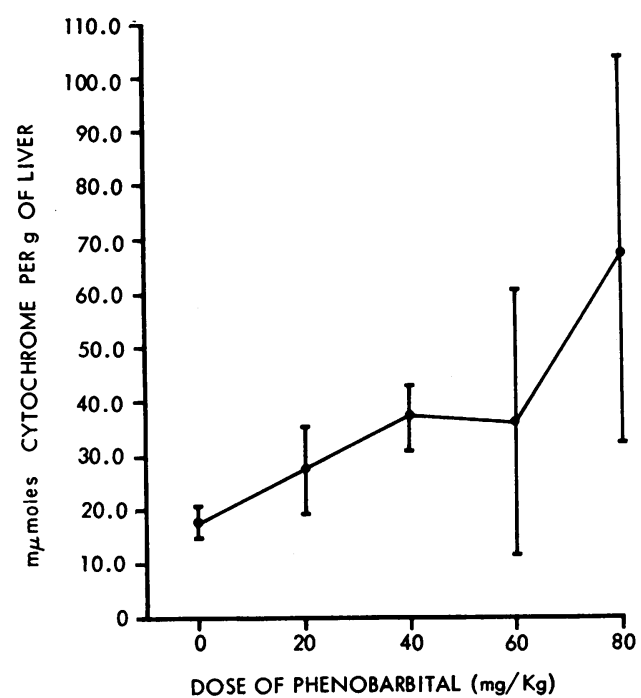

Figure 2 The levels of hepatic cytochrome P-450 in rats fed increasing doses of phenobarbital over a 5 day period. The results are shown as the mean \pm standard deviation for six control rats, five rats at $20 \mathrm{mg} / \mathrm{kg}$, four rats at $40 \mathrm{mg} / \mathrm{kg}$, eight at $60 \mathrm{mg} / \mathrm{kg}$, and six at $80 \mathrm{mg} / \mathrm{kg}$ of phenobarbital.

\section{Cycloheximide-treated rats}

\section{Hepatic Heme and Protein Synthesis}

The $90 \mathrm{~min}$ incorporation of glycine- $2-{ }^{14} \mathrm{C}$ into hepatic protein and delta ALA-4- ${ }^{14} \mathrm{C}$ into hepatic heme are shown in Fig. 3, along with the hepatic microsomal cytochrome P-450 at intervals up to $10 \mathrm{hr}$ after the administration of cycloheximide. Each point on the graph represents the mean of three to five animals. Protein synthesis as measured by glycine-2-14 $\mathrm{C}$ incorporation fell to approximately $10 \%$ of the control values in bile fistula rats within $2 \frac{1}{2} \mathrm{hr}$ and remained at levels of $20 \%$ or less for at least $10 \mathrm{hr}$ after cycloheximide administration.

The changes in hepatic cytochrome P-450 levels in phenobarbital-induced rats given cycloheximide are also shown in Fig. 3. Phenobarbital-induced animals were employed because of greater ease and sensitivity of assay in rats with high initial levels. $3 \mathrm{hr}$ after cycloheximide administration, cytochrome P-450 had dropped to one-third of its initial level and remained in this range over the 
TABLE II

Incorporation of Glycine-2-14 C and Delta $A L A-4-{ }^{14} \mathrm{C}$ into Bile Bilirubin in Phenobarbital-Treated Rats

\begin{tabular}{|c|c|c|c|c|c|c|}
\hline $\begin{array}{l}\text { Dose of } \\
\text { pheno- } \\
\text { barbital }\end{array}$ & Tracer & $\begin{array}{c}\text { Dose of } \\
\text { tracer }\end{array}$ & Condition & $\begin{array}{c}\text { No. of } \\
\text { animals }\end{array}$ & $\begin{array}{l}\text { Bilirubin: \% in- } \\
\text { corporation of } \\
\text { injected counts }\end{array}$ & $\begin{array}{l}\text { Total } 24 \mathrm{hr} \\
\text { excretion }\end{array}$ \\
\hline $\mathrm{mg} / \mathrm{kg}$ & & $\mu c$ & & & & $m g$ \\
\hline 0 & Glycine & 20 & Fed & 6 & $0.055 \pm 0.024$ & $1.17 \pm 0.22$ \\
\hline 0 & Glycine & 100 & Starved & 1 & 0.080 & 2.47 \\
\hline 40 & Glycine & 20 & Fed & 2 & $0.076 \pm 0.014$ & $1.30 \pm 0.27$ \\
\hline 60 & Glycine & 20 & Fed \& starved & 5 & $0.097 \pm 0.025$ & $1.47 \pm 0.16$ \\
\hline 80 & Glycine & 20 & Fed \& starved & 4 & $0.108 \pm 0.037$ & $1.68 \pm 0.30$ \\
\hline 80 & Glycine & 100 & -Starved & 1 & 0.234 & 1.98 \\
\hline 80 & Glycine & 100 & Starved & 1 & 0.093 & 1.71 \\
\hline 0 & Delta ALA & 1 & Fed & 8 & \pm 2.4 & $1.44 \pm 0.34$ \\
\hline 60 & Delta ALA & 1 & Fed \& starved & 3 & \pm 2.5 & $1.38 \pm 0.22$ \\
\hline 80 & Delta ALA & 1 & Fed \& starved & 2 & \pm 1.3 & $1.70 \pm 0.67$ \\
\hline
\end{tabular}

Delta ALA, delta aminolevulinic acid.

period of observation. In rats not induced with phenobarbital the control value of cytochrome P-450 was $0.946 \mathrm{~m} \mu \mathrm{moles} / \mathrm{mg}$ of microsomal protein (305 m $\mu$ moles/whole liver). This value dropped to $0.666 \mathrm{~m} \mu$ moles/mg (167 m momoles/ whole liver) within $1 \mathrm{hr}$ of cycloheximide injection.

The 90 min incorporation of delta ALA- ${ }^{14} \mathrm{C}$ into heme was $9.8 \%$ of the injected counts in the control bile fistula animals. In the cycloheximidetreated rats the incorporation was $7.8 \% 90 \mathrm{~min}$ after cycloheximide administration and remained at or above $6.0 \%$ for the entire period. Thus the incorporation of delta ALA-4- ${ }^{14} \mathrm{C}$ into heme in the cycloheximide animals remained in excess of $60 \%$ of the control values during the $10 \mathrm{hr}$ span of the experiment. The continued utilization of delta $\mathrm{ALA}-{ }^{14} \mathrm{C}$ for heme synthesis in the presence of a concentration of cycloheximide sufficient to block protein synthesis in an in vitro rabbit reticulocyte system was reported by Grayzel, Fuhr, and London (27).

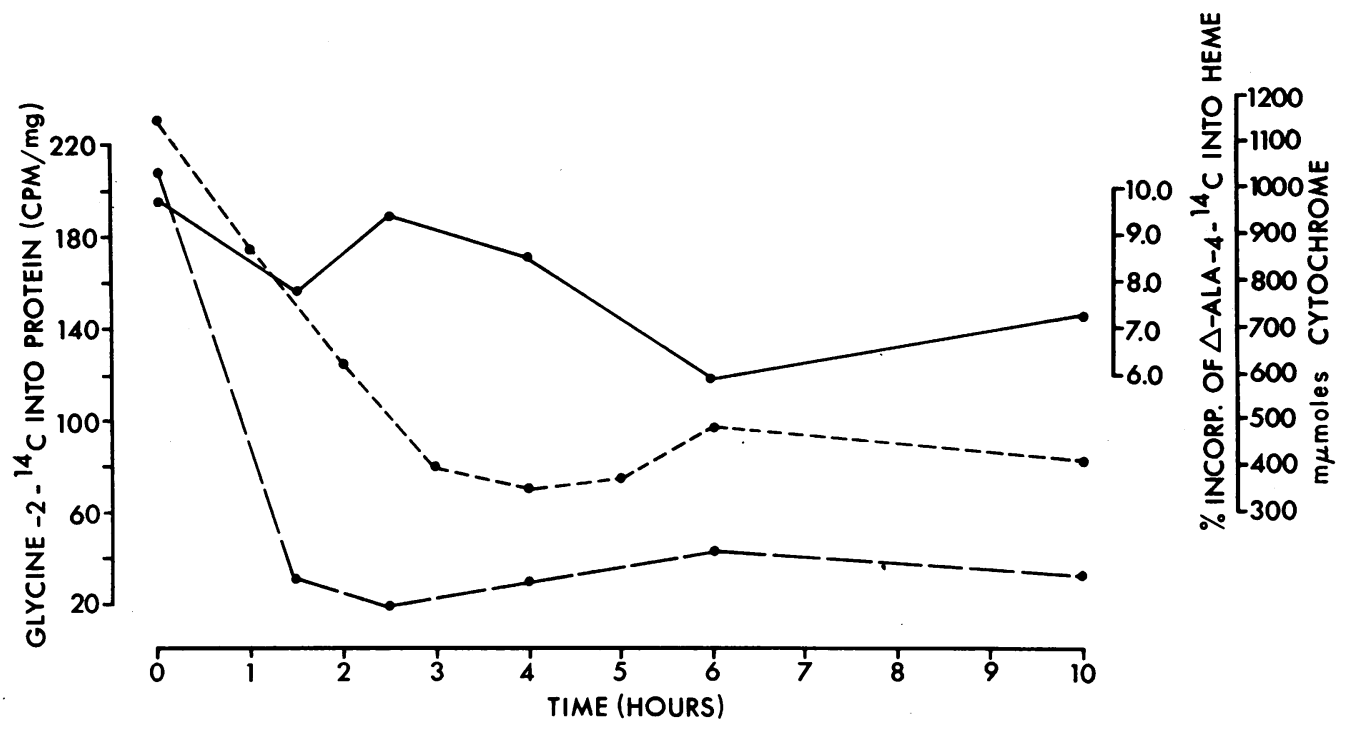

FIGURE 3 The incorporation of glycine- $2{ }^{14} \mathrm{C}$ into hepatic protein $(---)$, the incorporation of delta ALA-4- ${ }^{14} \mathrm{C}$ into hepatic heme (- - , and microsomal cytochrome $\mathrm{P}-450$ (-----) in rats injected with cycloheximide, $1 \mathrm{mg} / \mathrm{kg}$, at zero time. 
Delta ALA-4- ${ }^{14} \mathrm{C}$ Incorporation into Bile BiLIRUbiN

Rats remained in good condition for only 6-12 $\mathrm{hr}$ after cycloheximide and the bile flow decreased after $12 \mathrm{hr}$. The mean total bilirubin excretion for nine rats in the first $12 \mathrm{hr}$ was $0.610 \mathrm{mg} \pm 0.133$, $\mathrm{SD}$, as compared with a mean of $0.652 \mathrm{mg} \pm 0.185$, SD in 14 control animals.

The per cent incorporation of delta $\mathrm{ALA}-{ }^{14} \mathrm{C}$ into bile bilirubin in cycloheximide-treated bile fistula rats is shown in Fig. 4 and Table I. Fig. 4 depicts the mean and standard deviation in four rats given $1 \mu \mathrm{c}$ of delta $\mathrm{ALA}-4-{ }^{14} \mathrm{C} 1 \mathrm{hr}$ after 1 $\mathrm{mg} / \mathrm{kg}$ of cycloheximide as compared with the eight control animals. The mean $12 \mathrm{hr}$ incorporation of ${ }^{14} \mathrm{C}$ into bilirubin in these four rats was $29.6 \% \pm 7.5$, SD of the injected counts, which is significantly higher than the $12 \mathrm{hr}$ incorporation of $21.3 \% \pm 2.2 \mathrm{sD}$ in the controls $(P<0.02)$. Five bile fistula rats given delta ALA-4- ${ }^{14} \mathrm{C} 2 \frac{1}{2} \mathrm{hr}$ after cycloheximide excreted an average of $27.4 \% \pm$ 3.4. sn of the injected counts during the initial 12 $\mathrm{hr}$ period, which is also significantly higher than the control values $(P<0.01)$.

$1 \mathrm{hr}$ after cycloheximide, $1 \mathrm{mg} / \mathrm{kg}, 1 \mu \mathrm{c}$ of delta ALA-4- ${ }^{14} \mathrm{C}$ was given by intravenous catheter to a bile fistula rat followed $15 \mathrm{~min}$ later by $2 \mathrm{mg}$ of unlabeled delta ALA. Bile collection was begun after injection of the tracer. This rat incorporated $32.9 \%$ of the injected counts into bilirubin in the $24 \mathrm{hr}$ collection period. Although the incorporation for the 1 st hour was but $0.55 \%$, the remainder of the $24 \mathrm{hr}$ excretion pattern was comparable to those rats not given a chase of cold delta ALA. This observation supports the contention that the intravenous injection of delta $\mathrm{ALA}-4-{ }^{14} \mathrm{C}$ in rats is a true pulse, and that the delta $\mathrm{ALA}-4-{ }^{14} \mathrm{C}$ in the cycloheximide-treated rats was utilized at a time when protein synthesis was firmly suppressed.

The Excretion of Bilirubin- ${ }^{14} \mathrm{C}$ after InFUSION OF HEMIN- ${ }^{14} \mathrm{C}$

The bilirubin- ${ }^{14} \mathrm{C}$ excretion in two normal rats and in two rats given cycloheximide, $1 \mathrm{mg} / \mathrm{kg}, 1$

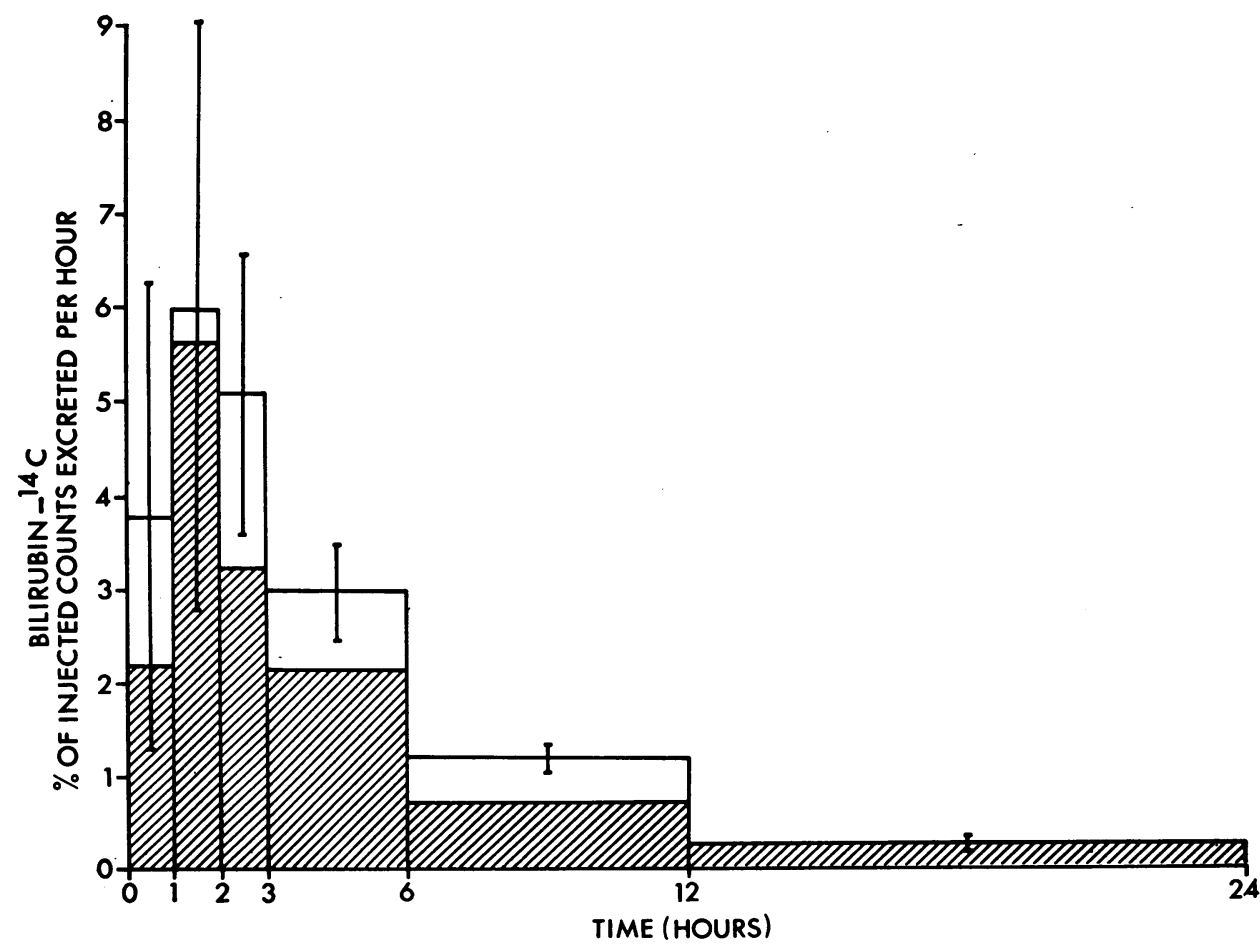

Figure 4 The excretion of bilirubin ${ }^{14} \mathrm{C}$ in four bile fistula rats given $1 \mathrm{mg} / \mathrm{kg}$ of cycloheximide $1 \mathrm{hr}$ before the injection of delta $\mathrm{ALA}-4-{ }^{14} \mathrm{C}$ at zero time. The results are expressed as the percentage (mean \pm standard deviation) of injected counts excreted per hour during each collection period. The cross-hatched area represents the control animals as shown in Fig. 1. 
TABLE III

Bilirubin- ${ }^{14} C$ Excretion in Normal and Cycloheximide-Treated Rats Infused with Hemin $-{ }^{14} C$

\begin{tabular}{|c|c|c|c|c|c|c|c|}
\hline \multirow[b]{2}{*}{$\mathrm{Hr} .}$. & & \multicolumn{5}{|c|}{ Interval of collection } & \multirow[b]{2}{*}{ Total } \\
\hline & & $0-1$ & $1-2$ & $2-3$ & 3-6 & 6-12 & \\
\hline \multirow{2}{*}{ Control } & ${ }^{14} \mathrm{C}$ in bilirubin, $\%$ & 3.2 & 5.3 & 3.2 & 8.6 & 8.2 & 28.5 \\
\hline & Bilirubin excretion, $m g$ & 0.08 & 0.15 & 0.10 & 0.26 & 0.43 & 1.02 \\
\hline \multirow{2}{*}{ Control } & ${ }^{14} \mathrm{C}$ in bilirubin, $\%$ & 5.6 & 6.6 & 3.9 & 9.4 & 11.5 & 37.0 \\
\hline & Bilirubin excretion, $m g$ & 0.13 & 0.14 & 0.11 & 0.29 & 0.47 & 1.14 \\
\hline \multirow{2}{*}{ Cycloheximide, $1 \mathrm{mg} / \mathrm{kg}$} & ${ }^{14} \mathrm{C}$ in bilirubin, $\%$ & 4.8 & 8.6 & 3.4 & 7.4 & 3.7 & 27.9 \\
\hline & Bilirubin excretion, $m g$ & 0.11 & 0.15 & 0.08 & 0.18 & 0.12 & 0.64 \\
\hline \multirow{2}{*}{ Cycloheximide, $1 \mathrm{mg} / \mathrm{kg}$} & ${ }^{14} \mathrm{C}$ in bilirubin, $\%$ & 8.4 & 10.6 & 4.1 & 7.4 & 8.3 & 38.8 \\
\hline & Bilirubin excretion, $m g$ & 0.22 & 0.21 & 0.14 & 0.28 & 0.92 & 1.77 \\
\hline
\end{tabular}

$\mathrm{hr}$ before an intravenous infusion of hemin $-{ }^{14} \mathrm{C}$ is shown in Table III. The total bilirubin and the bilirubin- ${ }^{14} \mathrm{C}$ excretion in the cycloheximidetreated animals is comparable to that in the control rats and does not suggest any impairment of uptake of heme, its conversion to bilirubin, nor its excretion in these animals.

\section{Bile duct obstruction}

It had previously been demonstrated that biliary obstruction in the rat produced a marked increase in incorporation of delta ALA-4- ${ }^{14} \mathrm{C}$ into bile bilirubin, along with a reduction in hepatic heme synthesis (10). However, the obstructed rats had retained a large load of unlabeled bilirubin that subsequently was excreted during the first $12 \mathrm{hr}$ after

TABLE IV

Glycine-2-14C Incorporation into Hepatic Protein and Hepatic Cytochrome P-450 in Normal, Bile Fistula, and Biliary-Obstructed Rats

\begin{tabular}{lccc}
\hline & $\begin{array}{c}\text { Normal } \\
\text { rats }\end{array}$ & $\begin{array}{c}24 \mathrm{Hr} \\
\text { post } \\
\text { fistula }\end{array}$ & $\begin{array}{c}\text { Bile duct } \\
\text { tied for } \\
48 \mathrm{hr}\end{array}$ \\
\hline $\begin{array}{l}\text { Glycine-2-14C } \\
\text { incorporation into } \\
\text { hepatic protein, }\end{array}$ & 88.4 & 136.0 & 111.5 \\
$\begin{array}{l}\text { cpm/mg } \\
\text { Mean }\end{array}$ & 84.8 & 261.7 & 170.3 \\
Cytochrome P-450, & 316.2 & 242.4 & 145.1 \\
$\quad$ mumoles/liver & 338.8 & - & 129.7 \\
& 267.3 & & 197.3 \\
& 300.8 & & 129.5 \\
Mean & 305.8 & & 154.4 \\
\hline
\end{tabular}

establishment of the bile fistula. These six rats excreted $4.01 \mathrm{mg} \pm 0.94$, sD of bilirubin in $24 \mathrm{hr}$ compared with $1.31 \mathrm{mg} \pm 0.31$, sD in the 14 controls $(P<0.01)$. The excretion of this retained load makes it difficult to interpret the kinetics of bilirubin labeling in obstruction since there is a delay in the appearance of the newly synthesized bilirubin.

In this study the effects of biliary obstruction on hepatic cytochrome $\mathrm{P}-450$ and on the incorporation of glycine-2-14 $\mathrm{C}$ into protein are given in Table IV. It is of interest that protein synthesis is enhanced by the surgical establishment of a bile fistula. This effect is reduced if a $48 \mathrm{hr}$ period of biliary obstruction precedes the establishment of the fistula and injection of the label. Biliary obstruction for $48 \mathrm{hr}$ is also associated with a reduction to about one-half in hepatic cytochrome P-450 as compared with normal rats.

\section{DISCUSSION}

The first component of the early bilirubin is considered to be of nonerythropoietic origin and may consist of two primary subcomponents (10). Labeled bilirubin appears in the bile within minutes of injection of delta ALA-4- ${ }^{14} \mathrm{C}$. This rapid appearance of a large fraction of the labeled bilirubin before maximum incorporation of the tracer into tissue heme suggested that it may be derived either from a pool of very rapidly turning over heme proteins or directly from degradation of free tissue heme or its precursors. Thereafter the turnover of the labeled tissue hemes of liver and kidney parallel the excretion of labeled bilirubin, and this 
second subcomponent was thought to be related to the turnover of the more slowly degraded tissue hemeproteins (e.g., catalase). The combined turnover of renal and hepatic hemes is of sufficient magnitude to account for all the early bilirubin, and the finding that the turnover of renal heme was of similar magnitude to that of hepatic heme suggested that it might constitute an important source of this bilirubin (10).

To assess the role of the kidney in early bilirubin production, the incorporation of delta ALA$4-{ }^{14} \mathrm{C}$ into bile bilirubin was measured in rats that had been subjected to bilateral nephrectomy. In four such animals, bilirubin labeling was increased despite the absence of the renal heme pool. As urinary excretion is a major route of delta ALA excretion (28) a parallel experiment was done in rats with ligated ureters. It is of interest that in the latter group the percentage of delta ALA $-4-{ }^{14} \mathrm{C}$ incorporation into bilirubin was similar to the controls despite the loss of this rapid route of delta ALA disposal. These findings suggest that the contribution of renal heme turnover to early bilirubin production is probably minor. It must be considered that heme reutilization or degradation by alternate pathways to catabolites other than bilirubin may occur in the kidney. A significant portion of the renal heme is heme $a$ rather than protoheme (29). The final products of the degradation of the heme $a$ group are unknown but may differ from bilirubin.

Previous speculation had suggested hepatic heme turnover as the major source of the nonerythropoietic component (4), and this hypothesis was supported by the isolated rat liver perfusion studies of Robinson, Owen, Flock, and Schmid (9) which demonstrated the synthesis of bilirubin from glycine and delta ALA in a manner which qualitatively and quantitatively resembled that found in the intact rat. Further, White, Silvers, Rother, Shafer, and Williams (30) reported that liver homogenate systems are able to synthesize bilirubin from glycine and delta ALA in vitro. Thus the liver may be the principal site of production of the nonerythropoietic component.

The precursors of the nonerythropoietic component of the early bilirubin are unknown, but there are several possible sources: $(a)$ from the turnover of hepatic heme proteins; $(b)$ from the degradation of "free" heme; $(c)$ from heme precursors.
The report of White and coworkers (30) that CO is produced along with bilirubin in a liver homogenate system suggests that tetrapyrrole synthesis precedes bilirubin production. These findings are against a direct pathway from delta ALA to bilirubin which does not involve the prior synthesis of porphyrin or heme. However, the possibility of a direct synthesis from porphobilinogen bypassing uroporphyrinogen III and protoporphyrin 9 is raised by Petryka who reported a bilirubin isomer other than $9 \alpha$ in the early labeled fraction (31).

Alterations in the synthesis of hepatic heme are associated with changes in the incorporation of delta ALA $-4-{ }^{14} \mathrm{C}$ into the early bilirubin. The inhibition of heme synthesis in the lead-treated rats was associated with a significant early decrease in bilirubin formation (Table I). However, in rats with ligated bile ducts a reduction in heme synthesis was present along with a marked increase in early bilirubin synthesis (10). These two studies indicate that the total heme synthesis is not directly related to the nonerythropoietic bilirubin, and that some parts of this heterogeneous heme pool are more important as precursors of this bilirubin than are others. That the presence of an increased pool of heme precursor does not result in an increase in this bilirubin fraction is shown in the AIA-treated porphyric rats in which the increase in early labeling was minimal. This modest increase in bilirubin synthesis in the presence of greatly increased porphyrin synthesis indicates that this pathway is not available for porphyrin disposal.

As to specific heme compounds which may be precursors of this bilirubin, a major hepatic heme protein is catalase. Since the half-life of catalase is approximately $30 \mathrm{hr}(32)$, its turnover would be reflected primarily in the second or more slowly appearing subcomponent of the nonerythropoietic early bilirubin. Higashi and Peters (33) found that rat liver contained about $1550 \mu \mathrm{g}$ of catalase per $g$ of wet liver. When the hematin concentration in hepatic catalase determined by Bonnichsen (34) is used there is about $195 \mu \mathrm{g}$ of heme in catalase in an average $15 \mathrm{~g}$ wet weight rat liver. If we assume a half-life of $30 \mathrm{hr}$ the contribution of the degradation of catalase heme to bilirubin would be $80 \mu \mathrm{g}$ of bilirubin, or about $7 \%$ of the total daily bilirubin output. This value would 
represent about one-half of the total early labeled bilirubin.

Aminotriazole causes a reduction in hepatic catalase by forming an inactive, irreversible complex with the protein molecule (13). The kinetics of disposal of this complex are unknown, but it was thought that formation of the inactive complex might be accompanied by an acceleration of catalase destruction and increased bilirubin labeling. No abrupt rise was observed, but a moderate but significant increase in bilirubin- ${ }^{14} \mathrm{C}$ excretion was observed over a $12 \mathrm{hr}$ period after aminotriazole in rats with prior labeling of tissue hemes by delta ALA $-4-{ }^{14} \mathrm{C}$. This is indirect evidence that catalase may make a contribution to this bilirubin component. However, the normal or increased early bilirubin production under circumstances of reduced hepatic catalase content such as experimental porphyria (12) and bile duct ligation (35) as well as the normal production of early labeled stercobilin in acatalasemia in man $^{2}$ suggests that the contribution of hepatic catalase to the early labeled bilirubin is less than that predicted on the basis of its pool size and half-life. It is therefore necessary to consider the possible role of the more rapidly turning over heme proteins.

Schmid and coworkers (11) were able to demonstrate enhanced incorporation of glycine-2- ${ }^{14} \mathrm{C}$ into bile bilirubin in Sprague-Dawley rats treated with $80 \mathrm{mg} / \mathrm{kg}$ of phenobarbital for 5 days. They observed a 3 - to 4 -fold increase in glycine- ${ }^{14} \mathrm{C}$ incorporation into bile bilirubin over a $48 \mathrm{hr}$ period after administration of glycine $-{ }^{14} \mathrm{C}$, whereas the bilirubin excretion in bile doubled. They also observed an 8-fold increase in the concentration of the liver microsomal cytochromes with the same dose of phenobarbital and suggested that cytochrome P-450 and perhaps cytochrome $b_{5}$ are major sources of the early appearing bilirubin.

When the concentration of cytochrome P-450 and its half-life in liver are known, it is possible to calculate its potential contribution to the total bilirubin excretion. With the data obtained in the present study, that is an average liver cytochrome P-450 concentration of $300 \mathrm{~m} \mu$ moles and a halflife of $135 \mathrm{~min}$, if all heme from the catabolism of

\footnotetext{
2 Yamamoto, T., M. Fujii, T. Inuki, and G. Wakisaka. Evidence for the presence of two components in early appearing bile pigments in man derived from studies on fecal stercobilin and coproporphyrin. Data to be published.
}

cytochrome $\mathrm{P}-450$ is degraded to bilirubin, its contribution to excreted bilirubin would be approximately $0.9 \mathrm{mg} / 24 \mathrm{hr}$. Since the $24 \mathrm{hr}$ bilirubin excretion approximates $1.5 \mathrm{mg}$, this would constitute some $60 \%$ of the total daily bilirubin excretion. This value in itself is much in excess of the total contribution of the entire early bilirubin to daily bilirubin excretion.

If cytochrome P-450 is a major source of the first component of the nonerythrupoietic early bilirubin, then a correlation should exist between the level of induced cytochrome P-450 and the early bilirubin. We were able to induce a 4-fold rise in cytochrome $\mathrm{P}-450$ in rats given phenobarbital at a dosage of $80 \mathrm{mg} / \mathrm{kg}$ per day for 5 days. It should be noted that rats treated with this high dose of phenobarbital were anorexic and rapidly lost weight, whereas those treated with phenobarbital at $60 \mathrm{mg} / \mathrm{kg}$ were well and ate normally. In those rats that were then given $20 \mu \mathrm{c}$ of glycine $-2{ }^{14} \mathrm{C}$, a significant increase in early labeling was observed at dose levels of 60 and $80 \mathrm{mg} / \mathrm{kg}$ (Table II). However, in the series of rats given delta ALA-4- ${ }^{14} \mathrm{C}$ there was no significant increase in ${ }^{14} \mathrm{C}$ incorporation into bile bilirubin in the rats treated with $60 \mathrm{mg} / \mathrm{kg}$, although a significant increase was observed in those rats pretreated with $80 \mathrm{mg} / \mathrm{kg}$ of phenobarbital.

These results are in partial agreement with those of Schmid and associates (11) who observed a much greater increase in early labeling after phenobarbital in a dosage of $80 \mathrm{mg} / \mathrm{kg}$ over a period of 5 days. This increase may in part be related to the greater induction of P-450 which they achieved or to the large tracer dose of $100 \mu \mathrm{c}$ of glycine used in their experiments. In one of two animals in our series given $100 \mu \mathrm{c}$ of glycine-2- ${ }^{14} \mathrm{C}$ a 4-fold increase in ${ }^{14} \mathrm{C}$ incorporation into bilirubin was obtained (Table II). Extrapolating from data on the daily excretion of glycine in man (36), rats receiving $100 \mu \mathrm{c}$ get in excess of $400 \mu \mathrm{g}$ of glycine, which would constitute more than $10 \%$ of the total daily excretion of glycine in a $300 \mathrm{~g}$ rat. This amount may well exceed a tracer dose, and its effect on the pathways of heme synthesis, bilirubin production, and excretion are unknown. Granick $(37,38)$ has shown that phenobarbital induces the synthesis of delta ALA synthetase in chick embryo liver cell culture. Since delta ALA synthetase is the rate-limiting enzyme 
for heme biosynthesis (39), phenobarbital induction may lead to increased synthesis of porphyrins and heme. That no increase in delta $\mathrm{ALA}-{ }^{14} \mathrm{C}$ incorporation into early bilirubin was observed in the $60 \mathrm{mg} / \mathrm{kg}$ and correspondingly much less in the $80 \mathrm{mg} / \mathrm{kg}$ group than in the glycine rats suggests that the effect of phenobarbital may be at the level of delta ALA synthetase. The observations of Schmid and coworkers (11) could then be explained on the basis of increased incorporation of tracer glycine into bilirubin due to induction of delta ALA synthetase with increased heme turnover along with but independent of the induction of cytochrome P-450.

The minimal effects on early bilirubin production brought about by changes in the hepatic heme protein turnover led us to examine early bilirubin synthesis under conditions of reduced protein synthesis. Cycloheximide was used to inhibit general protein synthesis. Within $3 \mathrm{hr}$ of cycloheximide administration, over-all hepatic protein synthesis was reduced, and cytochrome P-450 levels were depressed (Fig. 3). At the same time, incorporation of delta $\mathrm{ALA}-{ }^{14} \mathrm{C}$ into hepatic heme proceeded at rates between 60 and $100 \%$ of normal. During this interval bilirubin- ${ }^{14} \mathrm{C}$ synthesis and excretion took place at a significantly higher than normal rate, and this increase took place in the first $12 \mathrm{hr}$ period (Fig. 4 and Table I). These observations suggest that the nonerythropoietic early bilirubin is produced and excreted in normal or increased amounts when the synthesis and the amount of the rapidly turning over heme proteins is reduced. These heme proteins would include cytochrome P-450 and tryptophane pyrrolase which is also inhibited by cycloheximide (40). Thus the synthesis of this bilirubin may in part arise from tissue heme unassociated with its protein carrier. That free heme may be converted to bilirubin was shown by Snyder and Schmid in rats infused with hematin $-{ }^{14} \mathrm{C}(41)$ as well as those included in the present study. The conversion of intravenous protoporphyrin- ${ }^{14} \mathrm{C}$ to bilirubin in bile fistula $\operatorname{dogs}$ is less efficient with only $15 \%$ recovery in $24 \mathrm{hr}$ (42).

It is of interest that rats with extrahepatic biliary tract obstruction incorporate twice as much delta $\mathrm{ALA}-4-{ }^{14} \mathrm{C}$ into bile bilirubin as do normal rats, along with a reduction in total hepatic heme synthesis (10). In such animals, there is less hepatic protein synthesis than in the bile fistula group, whereas hepatic cytochrome $\mathrm{P}-450$ is reduced to about $50 \%$ of that in normals (Table IV). Thus under conditions in which total hepatic heme synthesis is decreased, bilirubin production may double. The reason for this is not clear, but it is possible that there is dissociation of heme and protein synthesis under these conditions which makes that heme which is synthesized more readily available for conversion to bilirubin.

Felicetti, Colombo, and Baglioni have demonstrated in the red cell system that heme and globin synthesis may take place separately with subsequent combination (43). If the synthesis of heme

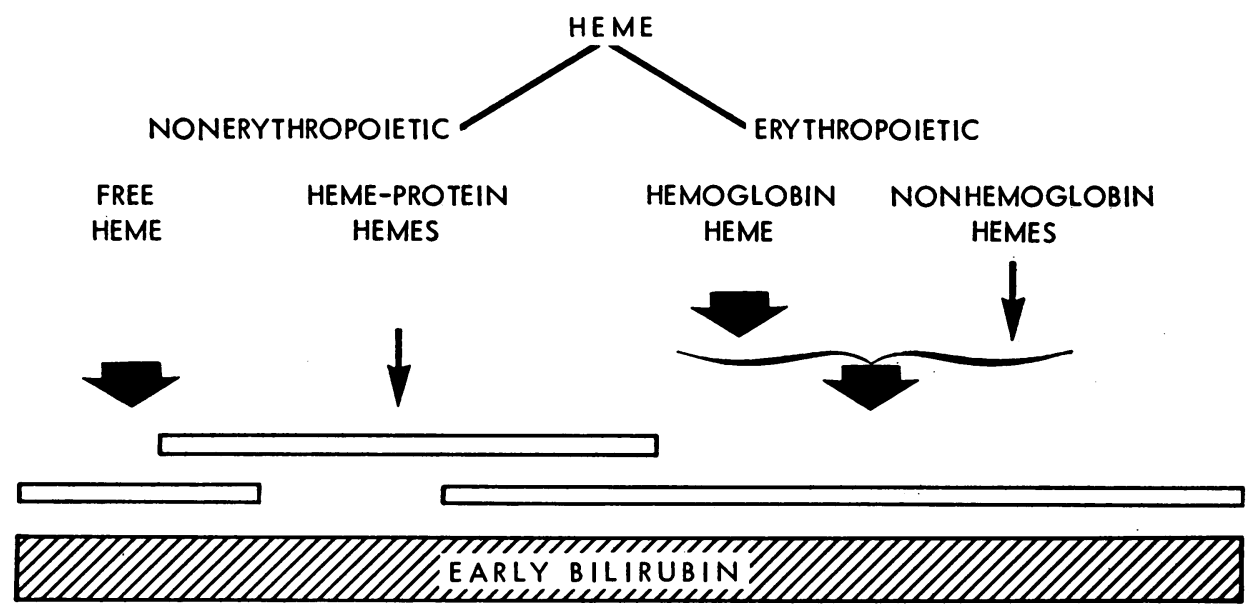

FIGURE 5 A proposed scheme for the origin of the early bilirubin indicating the sequence, sources, and relative contributions of the precursors. 
and its acceptor proteins occur independently in liver then the first subcomponent of the nonerythropoietic early bilirubin may represent heme formed in excess of its protein acceptor. The conversion to bilirubin would be a mechanism for ridding the liver of excess heme. Such a pathway for the regulation of the level of hepatic heme has been suggested by Granick (38). He has also produced evidence that in the liver, heme does not function as a direct inhibitor of delta ALA synthetase but as a repressor of its synthesis. Thus the autoregulatory mechanism for heme synthesis differs in liver from that known to exist in rabbit reticulocytes (44) and in Rhodopseudomonas spheroides (45) in which end product inhibition does occur. In liver the rapid elimination of excess heme may be a necessary adjunct to control by end product repression.

These observations on the nonerythropoietic component may be used to modify the concept of the origin of the early labeled bilirubin as previously postulated. The proposed components of this rapidly synthesized bilirubin are set forth schematically in Fig. 5. The erythropoietic component arises primarily from abortive hemoglobin synthesis, or from hemoglobin shed from developing or disintegrating red cell precursors. The nonhemoglobin hemes associated with red cell synthesis are also included in this component (8). The nonerythropoietic or tissue component arises primarily in the liver and may be derived in the main from uncombined heme. This is accompanied and followed by another element derived from heme protein turnover. The latter is a heterogeneous source depending in time on the half-lives of the contributing heme proteins.

\section{ACKNOWLEDGMENTS}

We are indebted to Mrs. Diane Ollmann and Miss Mary Jack for technical assistance and to Miss Nan Christie and Miss Isobel Steedman for preparation of the manuscript.

This work was supported by a grant from the Medical Research Council of Canada.

\section{REFERENCES}

1. London, I. M., R. West, D. Shemin, and D. Rittenberg. 1950. On the origin of bile pigment in normal man. J. Biol. Chem. 184: 351.

2. Gray, C. H., A. Neuberger, and P. H. A. Sneath. 1950. Studies in congenital porphyria. II. Incorpora- tion of ${ }^{15} \mathrm{~N}$ in the stercobilin in the normal and in the porphyric. Biochem. J. $47: 87$.

3. Ostrow, J. D., L. Hammaker, and R. Schmid. 1961. The preparation of crystalline bilirubin $-{ }^{14} \mathrm{C} . J$. Clin. Invest. 40: 1442.

4. Israels, L. G., T. Yamamoto, J. Skanderbeg, and A. Zipursky. 1963. Alternate pathways of bilirubin production. In Proceedings of the 9th Congress of the European Society of Haematology, Lisboa. 891.

5. Yamamoto, T., J. Skanderbeg, A. Zipursky, and L. G. Israels. 1965. The early-appearing bilirubin: evidence for two components. J. Clin. Invest. 44: 31.

6. Ibrahim, G. W., S. Schwartz, and C. J. Watson. 1966. Early labelling of bilirubin from glycine and deltaaminolevulinic acid in bile fistula dogs, with special reference to stimulated versus suppressed erythropoiesis. Metab. Clin. Exptl. 15: 1129.

7. Robinson, S. H., M. Tsong, B. W. Brown, and R. Schmid. 1966. The sources of bile pigment in the rat: studies of the "early labeled" fraction. J. Clin. Invest. 45: 1569.

8. Schwartz, S. 1967. Quantitation of erythropoietic and non-erythropoietic contribution to early labelling of bile pigments. In Bilirubin Metabolism. I. A. D. Bouchier and B. H. Billing, editors. Blackwell Scientific Publications Ltd., Oxford. 15.

9. Robinson, S. H., C. A. Owen, Jr., E. V. Flock, and R. Schmid. 1965. Bilirubin formation in the liver from nonhemoglobin sources. Experiments with isolated, perfused rat liver. Blood. 26: 823.

10. Israels, L. G., M. Levitt, W. Novak, J. Foerster, and A. Zipursky. 1967. The early bilirubin. In Bilirubin Metabolism. I. A. D. Bouchier and B. H. Billing, editors. Blackwell Scientific Publications, Ltd., Oxford. 1st edition. 3 .

11. Schmid, R., H. S. Marver, and L. Hammaker. 1966. Enhanced formation of rapidly labeled bilirubin by phenobarbital: hepatic microsomal cytochromes as a possible source. Biochem. Biophys. Res. Comm. 24: 319.

12. Schmid, R., J. F. Figen, and S. Schwartz. 1955. Experimental porphyria. IV. Studies of liver catalase and other heme enzymes in sedormid porphyria. $J$. Biol. Chem. 217: 263.

13. Margoliash, E., A. Novogrodsky, and A. Schejter. 1960. Irreversible reaction of 3-amino-1:2:4-triazole and related inhibitors with the protein of catalase. Biochem. J. 74: 339.

14. Goldberg, A., H. Ashenbrucker, G. E. Cartwright, and M. M. Wintrobe. 1956. Studies on the biosynthesis of heme in vitro by avian erythrocytes. Blood. 11: 821.

15. Bollman, J. L. 1948. A cage which limits the activity of rats. J. Lab. Clin. Med. 33: 1348.

16. Schwartz, S., and C. J. Watson. 1942. Isolation of a dextrorotatory urobilin from human fistula bile. Proc. Soc. Exptl. Biol. Med. 49: 641.

17. Malloy, H. T., and K. A. Evelyn. 1937. The determination of bilirubin with the photoelectric colorimeter. J. Biol. Chem. 119: 481. 
18. Labbe, R. F., and G. Nishida. 1957. A new method of hemin isolation. Biochim. Biophys. Acta. 26: 437.

19. Kassenaar, A., H. Morell, and I. M. London. 1957. The incorporation of glycine into globin and the synthesis of heme in vitro in duck erythrocytes. J. Biol. Chem. 229: 423.

20. Omura, T., and R. Sato. 1964. The carbon monoxidebinding pigment of liver microsomes. I. Evidence for its hemoprotein nature. J. Biol. Chem. 239: 2370.

21. Omura, T., and R. Sato. 1963. Fractional solubilization of hemoproteins and partial purification of carbon monoxide-binding cytochrome from liver microsomes. Biochim. Biophys. Acta. 71: 224.

22. Gorski, J., and M. C. Axman. 1964. Cycloheximide (actidione) inhibition of protein synthesis and the uterine response to estrogen. Arch. Biochem. Biophys. 105: 517.

23. Young, C. W., P. F. Robinson, and B. Sacktor. 1963. Inhibition of the synthesis of protein in intact animals by acetoxycycloheximide and a metabolic derangement concomitant with this blockade. Biochem. Pharmacol. 12: 855 .

24. Ennis, H. L., and L. Lubin. 1964. Cycloheximide: aspects of inhibition of protein synthesis in mammalian cells. Science. 146: 1474.

25. Remmer, H., and H. J. Merker. 1963. Drug-induced changes in the liver endoplasmic reticulum: association with drug metabolizing enzymes. Science. 142: 1657.

26. Remmer, H., and H. J. Merker. 1965. Effect of drugs on the formation of smooth endoplasmic reticulum and drug-metabolizing enzymes. Ann. N. Y. Acad. Sci. 123: 79.

27. Grayzel, A. I., J. E. Fuhr, and I. M. London. 1967. The effects of inhibitors of protein synthesis on the synthesis of heme in rabbit reticulocytes. Biochem. Biophys. Res. Comm. 28: 705.

28. Scott, J. J. 1955. The metabolism of $\alpha$-aminolevulinic acid. In Ciba Foundation Symposium on Porphyrin Biosynthesis and Metabolism. G. E. W. Wolstenholme and E. C. P. Millar, editors. J. \& G. Churchill Ltd., London. 43.

29. Lemberg, R. 1961. Cytochromes of Group A and their prosthetic groups. Advan. Enzymol. 23: 265.

30. White, P., A. A. Silvers, M. L. Rother, B. C. Shafer, and W. J. Williams. 1966. Hepatic production of bilirubin and carbon monoxide in vitro. J. Clin. Invest. 45: 1085

31. Petryka, Z. J. 1966. Identification of isomers differing from $9, \alpha$, in the early labelled bilirubin of the bile. Proc. Soc. Exptl. Biol. Med. 123: 464.
32. Price, V. E., W. R. Sterling, V. A. Tarantola, R. W. Hartley, Jr., and M. Rechcigl, Jr. 1962. The kinetics of catalase synthesis and destruction in vivo. J. Biol. Chem. 237: 3468.

33. Higashi, T., and T. Peters, Jr. 1963. Studies on rat liver catalase. I. Combined immunochemical and enzymatic determination of catalase in liver cell fractions. J. Biol. Chem. 238: 3945.

34. Bonnichsen, R. K. 1948. On the hematin and the bile pigments in catalase. Acta Chem. Scand. 2: 561.

35. Aronsen, K. F., and B. Haeger-Aronsen. 1963. Liver catalase activity during complete extra-hepatic biliary stasis in rabbits and dogs. Acta Physiol. Scand. 59: 486.

36. Dunn, M. S., M. N. Camien, S. Shankman, and H. Block. 1947. Urinary excretion of twelve amino acids by normal male and female subjects measured microbiologically. Arch. Biochem. 13: 207.

37. Granick, S. 1965. Hepatic porphyria and drug-induced or chemical porphyria. Ann. N.Y. Acad. Sci. 123: 188.

38. Granick, S. 1966. The induction in vitro of the synthesis of $\alpha$-aminolevulinic acid synthetase in chemical porphyria: a response to certain drugs, sex hormones, and foreign chemicals. J. Biol. Chem. 241: 1359.

39. Levere, R. D., and S. Granick. 1965. Control of hemoglobin synthesis in the cultured chick blastoderm by $\alpha$-aminolevulinic acid synthetase: increase in the rate of hemoglobin formation with $\alpha$-aminolevulinic acid. Proc. Natl. Acad. Sci. U. S. 54: 134.

40. Fiala, S., and E. Fiala. 1966. Induction of tyrosine transaminase in rat liver by actidione. Nature. 210: 530.

41. Snyder, A. L., and R. Schmid. 1965. The conversion of hematin to bile pigment in the rat. J. Lab. Clin. Med. 65: 817.

42. Ibrahim, G. W., S. Schwartz, and C. J. Watson. 1966. The conversion of protoporphyrin- $\mathrm{C}^{14}$ to heme compounds and bilirubin in dogs. Metab. Clin. Exptl. 15: 1120.

43. Felicetti, L., B. Columbo, and C. Baglioni. 1966. Assembly of hemoglobin. Biochim. Biophys. Acta. 129: 380.

44. London, I. M., G. P. Bruns, and D. Karibian. 1964. The regulation of hemoglobin synthesis and the pathogenesis of some hypochromic anemias. Medicine. 43: 789.

45. Lascelles, J. 1964. Tetrapyrrole Biosynthesis and its Regulation. W. A. Benjamin, Inc., New York. 1st edition. 